OPEN ACCESS

Edited by:

Chidananda Nagamangala Kanchiswamy,

Edmund Mach Foundation, Italy

Reviewed by:

Anil Khar,

Indian Agricultural Research Institute,

India

Ezio Portis,

University of Turin, Italy

*Correspondence:

Teodoro Cardi

teodoro.cardi@crea.gov.it

Specialty section:

This article was submitted to Crop Science and Horticulture,

a section of the journal

Frontiers in Plant Science

Received: 15 November 2016

Accepted: 08 February 2017

Published: 22 February 2017

Citation:

Cardi T, D'Agostino N and Tripodi P

(2017) Genetic Transformation

and Genomic Resources

for Next-Generation Precise Genome

Engineering in Vegetable Crops.

Front. Plant Sci. 8:241.

doi: 10.3389/fpls.2017.00241

\section{Genetic Transformation and Genomic Resources for Next-Generation Precise Genome Engineering in Vegetable Crops}

\author{
Teodoro Cardi *, Nunzio D’Agostino and Pasquale Tripodi \\ Consiglio per la ricerca in agricoltura e l'analisi dell'economia agraria (CREA), Centro di ricerca per l'orticoltura, \\ Pontecagnano Faiano, Italy
}

In the frame of modern agriculture facing the predicted increase of population and general environmental changes, the securement of high quality food remains a major challenge to deal with. Vegetable crops include a large number of species, characterized by multiple geographical origins, large genetic variability and diverse reproductive features. Due to their nutritional value, they have an important place in human diet. In recent years, many crop genomes have been sequenced permitting the identification of genes and superior alleles associated with desirable traits. Furthermore, innovative biotechnological approaches allow to take a step forward towards the development of new improved cultivars harboring precise genome modifications. Sequence-based knowledge coupled with advanced biotechnologies is supporting the widespread application of new plant breeding techniques to enhance the success in modification and transfer of useful alleles into target varieties. Clustered regularly interspaced short palindromic repeats (CRISPR)/CRISPR-associated protein 9 system, zinc-finger nucleases, and transcription activator-like effector nucleases represent the main methods available for plant genome engineering through targeted modifications. Such technologies, however, require efficient transformation protocols as well as extensive genomic resources and accurate knowledge before they can be efficiently exploited in practical breeding programs. In this review, we revise the state of the art in relation to availability of such scientific and technological resources in various groups of vegetables, describe genome editing results obtained so far and discuss the implications for future applications.

Keywords: vegetable crops, genome editing, in vitro regeneration, genetic transformation, whole genome sequences, genomics, breeding

\section{INTRODUCTION}

Vegetable crops include a large number of species belonging to various families, characterized by multiple geographical origins, large genetic variability and diverse reproductive features. As result of natural and artificial selection, various vegetables are differentially used worldwide for many purposes, either as fresh or processed products. Due to their nutritional value, vegetables have an important place in human diet, providing, in combination with freshness and taste, 
protection against various non-transmissible diseases and reduction of the so-called "hidden hunger" especially in developing countries (Desjardins, 2014).

Fast changes in climate and consumers' needs as well as the appearance of emerging and re-emerging plant pests and diseases require the continuous development of novel genotypes adapted to varying horticultural systems (Anderson et al., 2004). The availability of genetic resources plays an important role in such a process. Indeed, a large number of crop wild relatives and local traditional varieties is conserved in situ and ex situ by private or public institutions. In addition, local vegetable varieties (landraces) are still grown and reproduced by farmers, based on their adaptation to specific environments and on the presence of valuable traits. New genomics and phenomics tools allow the throughout characterization of such resources and should facilitate their better use in breeding. Nonetheless, the overall level of biodiversity in horticultural systems is decreasing, with threats to their economic, social, and environmental sustainability (Maggioni, 2004; Silva Dias, 2014).

New plant breeding techniques, in particular gene transfer based on cisgenic approaches and next-generation precision genome engineering relying on genome editing technologies, can play a key role in accessing genetic resources and using them in functional studies and streamlined breeding strategies (Cardi, 2016) (Figure 1). Such approaches, however, require efficient transformation protocols as well as extensive genomic resources and accurate knowledge before they can be efficiently exploited in practical breeding programs. In this review, we revise the state of the art in relation to availability of such scientific and technological resources in various groups of vegetables, describe genome editing results obtained so far and discuss the implications for future applications.

\section{REGENERATION AND TRANSFORMATION}

Available plant transformation methods include indirect (i.e., requiring an intermediate biological vector, usually the bacterium Agrobacterium tumefaciens) and direct methods (electroporation or PEG-mediated transformation of protoplasts, biolistics, etc.; Finer, 2010). Successful transformation, however, relies on various phases, being the introduction and integration of DNA into the plant genome as well as the selection and regeneration of transformed cells the most important and, sometimes, limiting factors (Wędzony et al., 2014; Altpeter et al., 2016). Regeneration of transformed plants has been extensively pursued in vegetable crops, although large differences in efficiency among families, species, and cultivars have been reported (Klocke et al., 2010). Plant regeneration is generally achieved via in vitro culture systems, using a range of explants and following two alternative pathways: de novo shoot organogenesis (DNSO) or somatic embryogenesis (SE; Wędzony et al., 2014).

Within the Solanaceae family, eggplant (Solanum melongena) and, to a lesser extent, tomato ( $S$. lycopersicum) have been successfully subjected to genetic transformation with various purposes using different approaches (Klocke et al., 2010). Regeneration in eggplant has been obtained either through SE or DNSO starting from protoplasts, tissue explants, microspores (Rotino et al., 2014). In tomato, Agrobacterium-mediated transformation of cotyledon explants has been most frequently achieved, albeit protoplast protocols are also available. Genetic variability of response to both in vitro systems is well known (Kurtz and Lineberger, 1983; Derks, 1992). The dominant Rg1 gene involved in regeneration capacity has been transferred from S. peruvianum into $S$. lycopersicum and subsequently mapped on chromosome 3 (Koornneef et al., 1993). Recently, its effect has been characterized in a different genetic background also

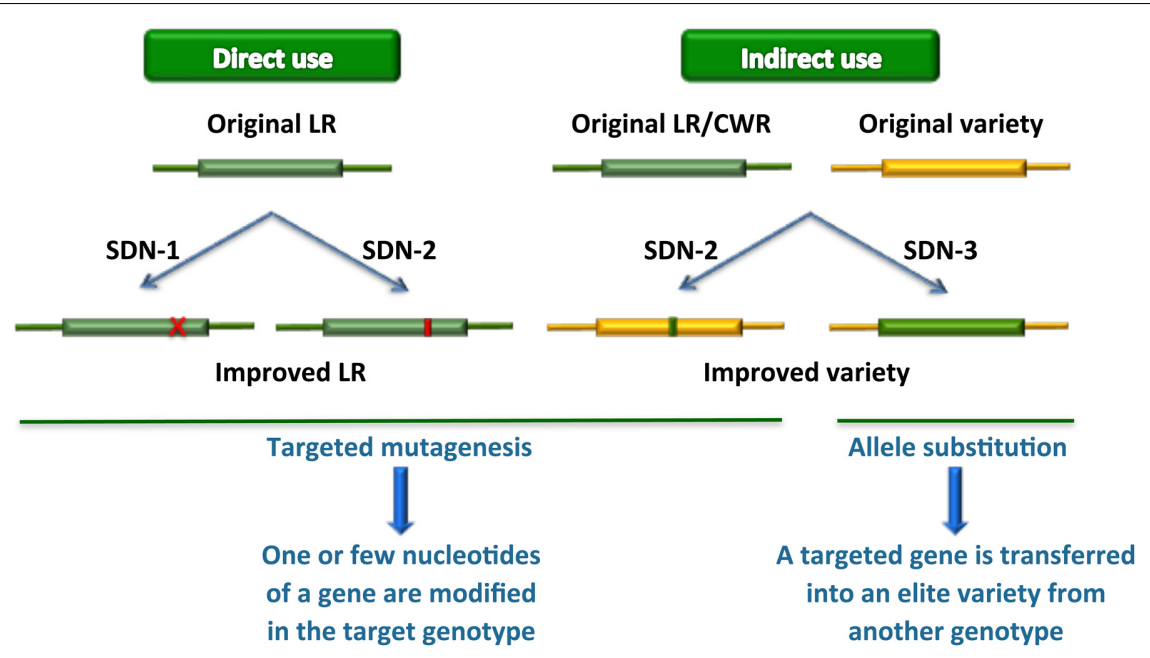

FIGURE 1 | Novel plant breeding techniques applied to the exploitation of genetic resources. LR, landraces; CWR, crop wild relatives. SDN-1, 2, 3, site-directed nuclease usage for gene knockout, gene editing or gene replacement/stacking, respectively. If the gene replaced by the latter approach derives from a sexually compatible genetic resource, it can be dubbed also as "cisgenesis at the same locus." 
in combination with other relevant genes (Pino et al., 2010; Lombardi-Crestana et al., 2012). By contrast, although some positive results have been reported (Klocke et al., 2010), pepper (Capsicum spp.) is considered a recalcitrant species due to several issues that jeopardize the in vitro response (Kothari et al., 2010). Some interesting results, however, based on the overexpression of two heterologous transcription factors involved in the regeneration process (i.e., WUSCHEL and BABY BOOM), have been recently published in sweet and chili pepper (SolísRamos et al., 2009; Heidmann et al., 2011).

Brassica oleracea and B. rapa include the majority of vegetables belonging to Brassicaceae. Transformation, usually achieved by inoculation of seedling explants with Agrobacterium (direct gene transfer using protoplasts has been also accomplished) followed by regeneration through organogenesis, is strongly dependent on the genotype and various other factors, being $B$. rapa genotypes more difficult to transform than $B$. oleracea ones, and cabbage (B. oleracea var. capitata) the most difficult type within the latter. A strong genetic component with significant additive effects both for A. tumefaciens susceptibility and regeneration ability from cotiledonary explants as well as from leaf protoplasts has been found in B. oleracea [(Sparrow et al., 2004) and references cited therein], suggesting the possibility to incorporate those traits in recalcitrant genotypes by transferring the relevant genes. Raphanus sativus, another vegetable of the same family, is considered recalcitrant and only few reports are available. Advances in regeneration and transformation in this group of crops have been reviewed elsewhere (Vinterhalter et al., 2007; Klocke et al., 2010; Sparrow et al., 2011; Park et al., 2012; Kumar and Srivastava, 2016). With the aim to avoid tissue culture systems, similarly to the related species Arabidopsis thaliana, in planta transformation systems based on floral dipping or flower bud microinjection have been also attempted in various genotypes (Curtis and Nam, 2001; Sparrow et al., 2011).

Within the Cucurbitaceae family, transformation has been accomplished in all the three genera including vegetable crops: Cucumis (cucumber and melon), Cucurbita (squash, pumpkin and zucchini), and Citrullus (watermelon). Various (young) explants have been generally inoculated with Agrobacterium followed by regeneration through shoot organogenesis, but transformation efficiency varied largely with the genotype used (Klocke et al., 2010; Manamohan et al., 2011). Some improvements in the protocol have been lately reported for melon (Bezirganoglu et al., 2014; Zhang et al., 2014), cucumber (Wang et al., 2015), Cucurbita spp. (Nanasato et al., 2013), and watermelon (Liu et al., 2016). In the latter species, an efficient regeneration procedure via SE from embryogenic calli derived from leaf explants has been also recently published (Vinoth and Ravindhran, 2015). Attempts to develop in planta methods (either via pollen tube or microinjection of the shoot apical meristem) have been made in watermelon and cucumber (Chen et al., 1998; Baskaran et al., 2016). As far as genetic and molecular aspects of shoot regeneration are concerned, a simple dominant control of regeneration ability from leaf explants has been found in cucumber (Nadolska-Orczyk and Malepszy, 1989), while distinct expression profiles of WUSCHEL-related homeobox (WOX) genes have been associated with different regeneration abilities in watermelon (Zhang N. et al., 2015).

Among Asteraceae, lettuce (Lactuca sativa) and chicory (Cichorium intybus) have been largely and successfully used in many transformation experiments for a variety of purposes, using either Agrobacterium inoculation of various explants (mainly cotyledons and true leaves) or direct gene transfer (electroporation/PEG treatment of protoplasts or particle bombardment of tissue explants) (Davey et al., 2007; Klocke et al., 2010; Song et al., 2014; Matvieieva, 2015). Shoot regeneration from hairy roots has also been accomplished. Regeneration normally proceeds by organogenesis, but SE has also been reported. Recently, the "surface response" method has been employed in lettuce to optimize plant regeneration (Gómez-Montes et al., 2015). While a mature regeneration/transformation technology is available for both above-mentioned species, de novo shoot regeneration and cell transformation have been observed only sporadically and with very low efficiency in another important vegetable of this family, i.e., globe artichoke (Cynara cardunculus var. scolymus; Menin et al., 2012).

Carrot (Daucus carota), a member of the Apiaceae family, is considered a model species for in vitro SE. Factors affecting transformation efficiency have been defined in the late 1980 - early 1990. Subsequently, genetic transformation has been pursued for various objectives using either indirect (A. tumefaciens and A. rhizogenes) or direct gene transfer methods (electroporation/PEG-mediated transformation of protoplasts and biolistics) (Punja et al., 2007; Baranski, 2008; Klocke et al., 2010). Much less work has been performed in other vegetables of the same family, such as fennel (Foeniculum vulgare), celery (Apium graveolens), and parsley (Petroselinum crispum; Baranski, 2008; Klocke et al., 2010). Fennel is able to regenerate in vitro by either organogenesis or embryogenesis, albeit with a marked genotypic effect (Anzidei et al., 2000; Jakhar and Choudhary, 2012; Saxena et al., 2012), but no transgenic plants have been generated. A reproducible protocol has been developed for rapid and efficient production of transgenic celery plants via somatic embryo regeneration from A. tumefaciensinoculated leaf sections, cotyledons, and hypocotyls (Song et al., 2007). Only transgenic calli have been obtained in parsley (Baranski, 2008).

Successful Agrobacterium-mediated transformation in the leafy vegetable Spinacia oleracea (Chenopodiaceae) has been first published in 1995 and later applied for transferring agronomically relevant genes (Klocke et al., 2010). In the meantime, efforts have been made to improve transformation and regeneration procedures. Although the genotype has generally shown a significant effect, regeneration has been achieved either through organogenesis or embryogenesis depending mainly on the explant type and auxin/cytokinin ratio: cotyledon explants and low ratios facilitate the former, whereas root explants and high ratios favor the latter. In addition, low temperature $\left(14^{\circ} \mathrm{C}\right)$, photoperiod, light intensity, and $\mathrm{GA}_{3}$ content had substantial effects on shoot regeneration (Geekiyanage et al., 2006; Chin et al., 2009; Nguyen et al., 2013b), while low levels of hygromycin $\left(0.5 \mathrm{mg} \mathrm{l}^{-1}\right)$ have been found to promote SE (Milojević et al., 
2012). An optimized regeneration protocol has been recently published (Nguyen et al., 2013a).

Vegetable legumes (harvested as green immature pods and seeds or, e.g., in cowpea, also as leaves) and pulses (harvested for the dry seed) have long been considered as recalcitrant to in vitro transformation and regeneration, although significant progress has been shown in the recent past (Somers et al., 2003; Klocke et al., 2010; Dewir et al., 2016; Gatti et al., 2016; Nguyen et al., 2016). Difficulties in achieving organogenesis and SE from differentiated tissues have prompted the development of regeneration/transformation protocols from meristematic tissues, but this has made difficult the selection of uniform (non-chimeric) transformed shoots. In several cases, the release of phenol oxidation products from explants cultured in vitro inhibits cell division and provokes tissue darkening and death, while rooting of regenerated shoots can be an additional critical step. All those problems have been encountered in applying genetic transformation to common bean (Phaseolus vulgaris), that, compared to related species (e.g., P. acutifolius, P. coccineus, P. polyanthus), exhibits a lower regeneration potential. Nevertheless, various direct and indirect transformation methods have been attempted in this species, showing some interesting results (Veltcheva et al., 2005; Hnatuszko-Konka et al., 2014). The improvement of the in vitro selection step through the use of a systemic herbicide has resulted in a significant increase of transformation efficiency (Aragão and Campos, 2007). Recently, it has been shown that the endogenous hormonal content in embryogenic calli could be altered and SE increased by down-regulating the expression of the PvTRX1h gene, encoding for a histone methyltransferase (Barraza et al., 2015). Genetic engineering problems and efforts similar to those described for $P$. vulgaris have been recently reviewed in the related species Vigna unguiculata, for which electroporation, biolistics and Agrobacterium-based methods have all been used, the latter being the most common (Citadin et al., 2011). Due to the involvement of meristematic tissues in the regeneration process, also for this species it has been necessary to develop alternative selection regimes for increasing the recovery of transformed shoots (Aragão and Campos, 2007; Bakshi et al., 2012; Bakshi and Sahoo, 2013). Similarly to other legumes, also in garden pea (Pisum sativum), first transformed in the late 1980, meristems have been the explants of choice, but the transformation protocols have been gradually improved and successfully employed for various purposes, although a strong genotypic effect has been shown (Klocke et al., 2010; Mikschofsky and Broer, 2012). The broad bean (Vicia faba) is probably one of the most difficult legume species to regenerate and transform, requiring particular efforts to solve the problem of tissue blackening in vitro (Klenotičová et al., 2013), and only few successful experiments have been reported using Agrobacteriummediated transformation of meristematic cells or stem segments [reviewed in (O'Sullivan and Angra, 2016)]. Due to the intrinsic difficulties of legume regeneration systems, a range of methods not requiring tissue culture of explants have been proposed (Somers et al., 2003), including the electroporation of nodal axillary buds in pea and cowpea (Chowrira et al., 1996), the Agrobacterium inoculation of germinating seeds in pea and bean (Liu et al., 2005; Svabova et al., 2005), the inoculation of flower buds in cowpea (Ilori and Pellegrineschi, 2011).

Onion, shallot, garlic, leek (Amaryllidaceae), and asparagus (Asparagaceae), as other Monocotyledons, have been initially considered recalcitrant to in vitro regeneration and not amenable to Agrobacterium-mediated genetic transformation. Subsequently, however, several approaches have been developed [reviewed in (Gantait et al., 2010; Klocke et al., 2010)]. In onion and shallot (Allium cepa), either immature zygotic embryos or young calli derived from mature embryos have been successfully used as explants in Agrobacterium-mediated transformation experiments, but the former approach can rely on a higher availability of explants during the year (Eady et al., 2000; Zheng et al., 2001). Using the zygotic embryo-derived calli, shallot genotypes gave better results than onion ones. Furthermore, to overcome some limits of both embryo-based protocols, embryogenic calli initiated from seedling radicles have been used both with Agrobacterium and biolistic systems, showing comparable results (Aswath et al., 2006). Agrobacterium and biolistic approaches have been applied for garlic (A. sativum) as well. Either immature zygotic embryos, similarly to onion, or calli from root segments have been transformed via Agrobacterium, the former approach being successful also with leek (A. porrum; Zheng et al., 2004; Eady et al., 2005). However, the difficulty to get seed-derived tissues has recently prompted the development of alternative methods based on immature leaf tissues (Kenel et al., 2010) or roots from in vitro plantlets (Ahn et al., 2013). Finally, transformation in Asparagus officinalis has been demonstrated as early as in the ' 90 with a range of approaches, including Agrobacterium, protoplast electroporation, and biolistics (Klocke et al., 2010), but regeneration and transformation protocols have not been developed further.

The availability of in vitro culture and genetic transformation protocols for various vegetables is summarized in Table $\mathbf{1 .}$

\section{GENOMIC RESOURCES}

Next-Generation Sequencing technologies have determined a significant advancement in data generation. Indeed, large datasets are now being generated across various model and non-model plant species by sequencing whole genomes and/or by applying genome reduction strategies (i.e., RNA-sequencing, hybridization-based enrichment, restriction enzyme-based enrichment, etc.). The list of vegetable crops with publicly available complete or draft genome sequences is getting rich very quickly (Michael and VanBuren, 2015).

Within the Solanaceae family, complete genome sequences have been assembled, annotated, and published in different species, allowing the development of multiple publicly available resources $^{1}$ (Fernandez-Pozo et al., 2015). The genomes of the cultivated tomato (Heinz 1706) and its wild ancestor (S. pimpinellifolium) were published in 2012 (Tomato Genome Consortium, 2012). The genome sequence of S. pennellii, a

\footnotetext{
${ }^{1}$ https://solgenomics.net/
} 
TABLE 1 | Availability of in vitro regeneration/genetic transformation protocols and of genomic resources for some vegetable crops.

\begin{tabular}{|c|c|c|c|c|}
\hline Family & Cultivated species & Estimated genome size $(\mathrm{Mb})^{\mathrm{a}}$ & Regeneration and transformation ${ }^{b}$ & Genomic resources $^{c}$ \\
\hline \multirow[t]{3}{*}{ Solanaceae } & Solanum lycopersicum & 900 & $++/+++$ & +++ \\
\hline & Solanum melongena & 1130 & +++ & ++ \\
\hline & Capsicum annuum & 3300 & - & $++/+++$ \\
\hline \multirow[t]{3}{*}{ Brassicaceae } & Brassica rapa & 284 & ++ & ++ \\
\hline & Brassica oleracea & 378 & ++ & ++ \\
\hline & Raphanus sativus & 529 & - & + \\
\hline \multirow[t]{5}{*}{ Cucurbitaceae } & Cucumis sativus & 350 & ++ & +++ \\
\hline & Cucumis melo & 375 & ++ & +++ \\
\hline & Citrullus lanatus & 425 & ++ & ++ \\
\hline & Cucurbita pepo & 538 & ++ & + \\
\hline & Cucurbita maxima & 450 & ++ & - \\
\hline \multirow[t]{3}{*}{ Asteraceae } & Lactuca sativa & 2700 & +++ & + \\
\hline & Cichorium intybus & $1300-1400$ & ++ & + \\
\hline & Cynara cardunculus & 1084 & - & ++ \\
\hline Chenopodiaceae & Spinacia oleracea & 1002 & ++ & + \\
\hline \multirow[t]{4}{*}{ Apiaceae } & Daucus carota & 473 & +++ & ++ \\
\hline & Foeniculum vulgare & 4450 & $-/+$ & - \\
\hline & Apium graveolens & 3000 & $-/+$ & - \\
\hline & Petroselinum crispum & 2201 & - & - \\
\hline \multirow[t]{4}{*}{ Leguminosae } & Phaseolus vulgaris & 587 & + & +++ \\
\hline & Vigna unguiculata & 620 & + & - \\
\hline & Pisum sativum & 4300 & + & - \\
\hline & Vicia faba & 13000 & + & - \\
\hline \multirow[t]{3}{*}{ Amaryllidaceae } & Allium cepa & 16000 & $+/++$ & + \\
\hline & Allium sativum & 15901 & + & - \\
\hline & Allium porrum & 28607 & - & - \\
\hline Asparagaceae & Asparagus officinalis & 1308 & $-/+$ & + \\
\hline
\end{tabular}

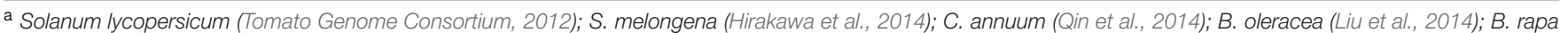

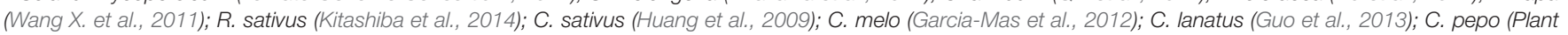

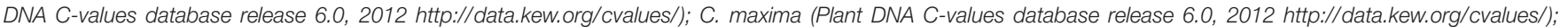

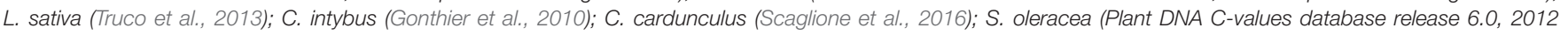

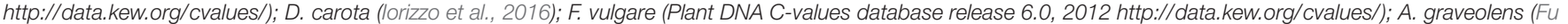

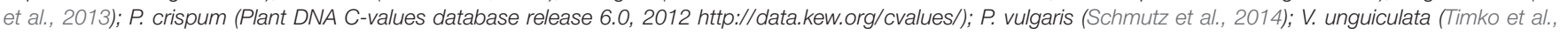

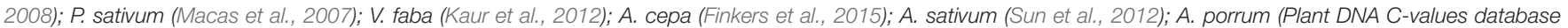
release 6.0, 2012 http://data.kew.org/cvalues/); A. officinalis (Li et al., 2014).

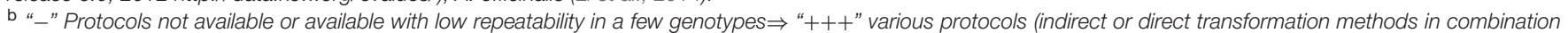
with different explant types, regeneration through DNSO or SE either from tissue explants or protoplasts) available for multiple genotypes.

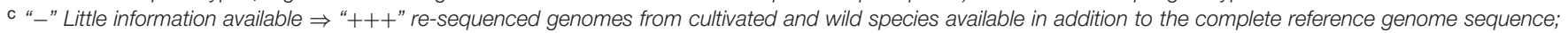
functional information available.

wild tomato species used as gene donor for the cultivated S. lycopersicum because of its extreme tolerance to abiotic stresses, was released in 2014 (Bolger et al., 2014). Its sequencing is enhancing the use of the already available introgression lines (ILs), in which genomic regions of S. lycopersicum are replaced with the corresponding segments of $S$. pennellii. Those publications allowed several re-sequencing projects to be developed with different scientific purposes (100 Tomato Genome Sequencing Consortium, 2014; Lin T. et al., 2014). Such recent efforts have led to the accumulation of a huge amount of valuable data on sequence diversity in the tomato clade that are of practical importance in the design of effective breeding strategies based on the generation of precise sequence changes in the target genome. In parallel, genome-wide association studies (GWAS) are revealing thousands of genetic variations associated with agronomically important traits (Ranc et al., 2012; Shirasawa et al., 2013; Ruggieri et al., 2014; Sauvage et al., 2014; Zhang J. et al., 2015), while much less numerous are the studies that rely on targeted enrichment methods for the discovery of genome-wide sequence variations from specific candidate loci (Terracciano et al., 2016).

Whole genome sequences of the hot (C. annuum cv. CM334) as well as of the cultivated pepper Zunla-1 (C. annuum L.) and its wild progenitor Chiltepin (C. annuum var. glabriusculum) have been released into the public domain together with re-sequencing data of cultivated, semi-wild/wild accessions (Kim et al., 2014; Qin et al., 2014). Genome resequencing of representative pepper accessions as well as single nucleotide polymorphism (SNP) discovery through genotyping by sequencing (Ahn et al., 2016; Taranto et al., 2016) have allowed genetic diversity in pepper 
to be unlocked. Nevertheless, the association between DNA variation and the observed phenotypic variability is still poor (Nimmakayala et al., 2016a).

A draft genome sequence of eggplant is also available (Hirakawa et al., 2014). An additional sequencing effort by an Italian consortium aiming at the generation of a gold-standard reference genome is ongoing (Barchi et al., 2016). Based on a fairly large number of accessions, a couple of GWAS have been published so far in eggplant allowing a series of novel marker/trait associations to be detected (Cericola et al., 2014; Portis et al., 2015).

Within the Brassicaceae, the sequencing of the B. rapa genome (Wang X. et al., 2011) has been followed by the release of the draft genome assembly of B. oleracea (Liu et al., 2014), a species characterized by a large morphological diversity and including different crops such as cauliflower, broccoli, cabbages, Brussels sprouts, kohlrabi, and kales. The investigation on the genetic variability in these species is still quite limited (Lin $\mathrm{K}$. et al., 2014).

Within the Cucurbitaceae family, the complete genome of cucumber (C. sativus L.) and melon (C. melo L.) as well as the draft genome of watermelon (C. lanatus) and zucchini (C. pepo) are already available (Huang et al., 2009; GarciaMas et al., 2012; Guo et al., 2013) ${ }^{2}$. In case of C. lanatus the resequencing of 20 accessions has also been performed (Guo et al., 2013) providing a large source of haplotype data with great potential for next-generation breeding. In addition, medium to large SNP catalogs generated by genotyping by sequencing are available in watermelon (Nimmakayala et al., 2014) and melon (Nimmakayala et al., 2016b). The latter has been used to perform GWAS for fruit firmness. In the near future, it is also expected the publication of the pumpkin (C. maxima Duch.) genome sequence ${ }^{3}$.

The genome of the globe artichoke (C. cardunculus var. scolymus), a species belonging to the Asteraceae, was released in 2016 (Scaglione et al., 2016), while the first draft of the lettuce (Lactuca sativa) and chicory (Cichorium intybus) genomes has been announced ${ }^{4}$ (Galla et al., 2014). A transcriptome-based SNP discovery, through Illumina sequencing of 11 representative accessions of the three C. cardunculus taxa generated $195 \mathrm{k}$ variants (Scaglione et al., 2012). More recently, a re-sequencing approach, followed by a whole genome SNP mining strategy, as well as the identification of PAV (presence-absence variation), have been applied for globe artichoke (Acquadro et al., 2016).

A high quality chromosome-scale assembly of carrot (Daucus carota subsp. carota L.) genome is now available (Iorizzo et al., 2016) for the scientific community interested in the Apiaceae genetic improvement. Transcriptome-based analysis on the allelic diversity of wild and cultivated accession is also available (Iorizzo et al., 2013).

Common bean ( $P$. vulgaris L.) genomes of two genotypes from Andean and Mesoamerican gene pools (Schmutz et al.,

\footnotetext{
${ }^{2}$ https://cucurbigene.upv.es/genome-v3.2/

${ }^{3}$ http://www.icugi.org/cgi-bin/ICuGI/index.cgi

${ }^{4}$ https://gr.genomecenter.ucdavis.edu/
}

2014; Vlasova et al., 2016) have been published as part of the Leguminosae family. In addition, an International Consortium for Pea Genome Sequencing (PGS) has been formed to explore options for sequencing the pea genome that is particularly complex and large $\left(\sim 4.3 \mathrm{~Gb}^{5}\right)$. Several GWAS have been performed in common bean to explore broader genetic diversity in order to establish marker-trait associations for future application in breeding programs (Cichy et al., 2015; Kamfwa et al., 2015; Perseguini et al., 2016).

Knowledge on Amaryllidaceae and Asparagaceae genomes is scarce compared to Solanaceae and Cucurbitaceae. Genomic resources for garlic (Allium sativum L.), onion (A. cepa L.), and asparagus (Asparagus officinalis L.) are limited because of their large, extremely complex, repetitive, and often polyploid genomes and long generation times. Nevertheless, the Sequon - Onion Genome Sequencing project is underway ${ }^{6}$ with the main goal to generate a high quality sequence for the gene-rich regions of a doubled haploid (DH) onion line as a reference for the Amaryllidaceae family.

All these genome sequencing initiatives, usually paralleled by the generation of transcriptome-derived sequences in case of species of minor interest, have led to the development of cladeoriented databases dedicated to the genomics of specific crop families (Wang X. et al., 2011; Fernandez-Pozo et al., 2015) ${ }^{7}$. The genome size in various vegetables and the availability of genomic resources are summarized in Table $\mathbf{1}$.

\section{GENOME EDITING IN VEGETABLE CROPS}

Current genome editing approaches rely on the induction of cuts in double-strand DNA (DSB, double-strand breaks), which are then "repaired" through two different processes: non-homologous end joining (NHEJ) or homology-directed repair (HDR; Cardi, 2016). In the former case, in the absence of foreign donor sequences, small changes (mostly frameshift mutations due to insertions and deletions) are induced in the original sequence during the repair process, generally resulting in the loss of function of the target gene and a mutated phenotype. On the other hand, if appropriate DNA fragments homologous to the target sequence are also inserted into the cell, they can, using the precise HDR mechanism, replace (correct) some nucleotide sequences of the gene to be modified or add new genes or regulatory elements in a predetermined position of the genome. Genome editing strategies recently applied to vegetable crops are reported in Table 2. In all but one case, they have been based on the induction of targeted mutations through NHEJ repair of DSBs determined by either transcription activator-like effector nucleases (TALEN) or clustered regularly interspaced short palindromic repeats/CRISPR-associated 9 endonuclease system (CRISPR/Cas9).

\footnotetext{
${ }^{5}$ https://www.france-genomique.org/spip/spip.php?article141\&lang=fr

${ }^{6} \mathrm{http}: / /$ www.oniongenome.net/

${ }^{7}$ http://www.icugi.org/cgi-bin/ICuGI/index.cgi
} 


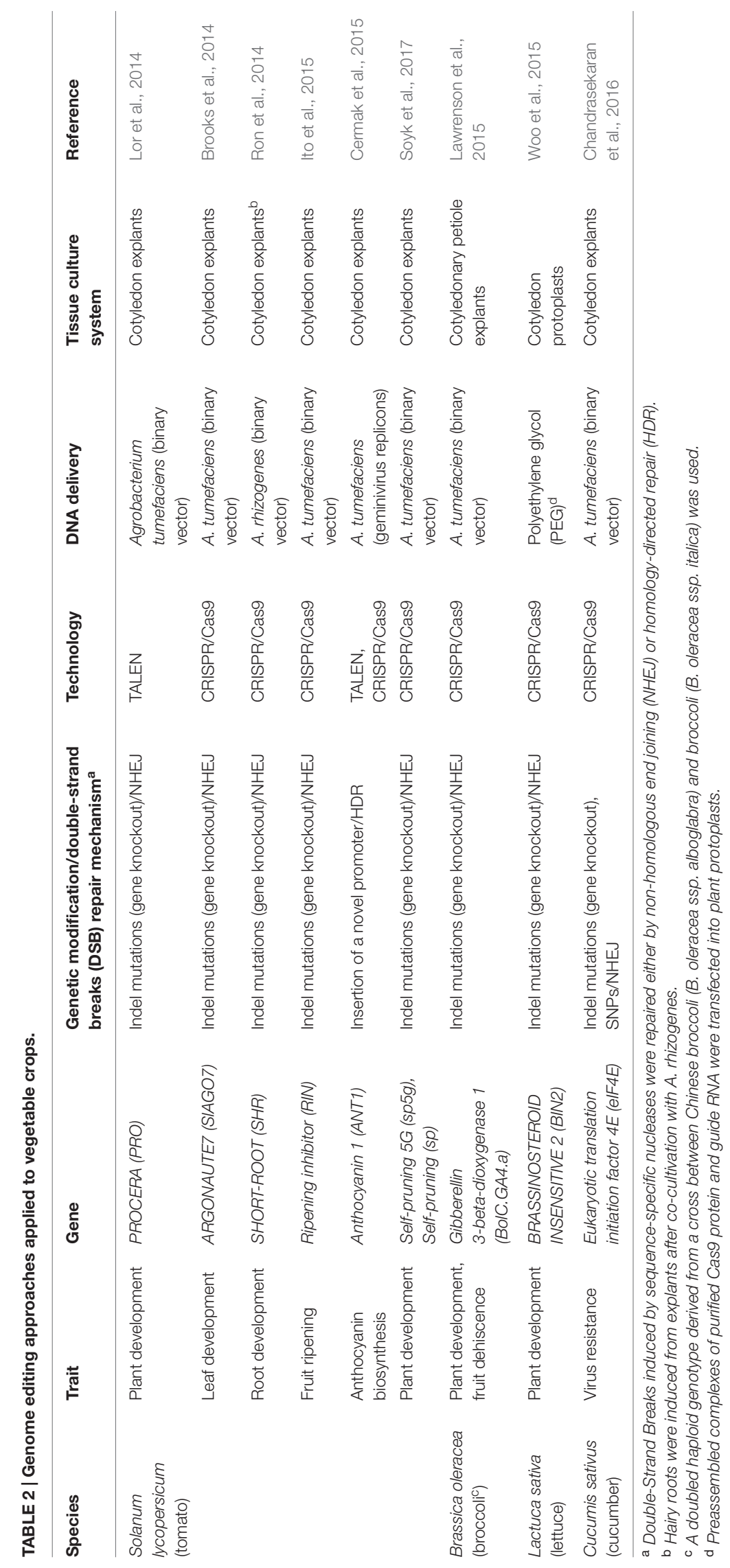


In tomato, TALE nucleases under the control of an estrogeninducible promoter have been used to knockout one DELLA gene $(P R O)$ involved in negative regulation of gibberellic acid (GA) signaling. Consistently with the induction of frameshift mutations, loss of DELLA function and increased GA response, plants carrying two different mutant alleles (biallelic) or the same mutation in homozygous condition showed longer internodes than the wild type and lighter green leaves with smoother margins. Induced pro mutations were transmitted to the progenies according to Mendelian inheritance, while the transgene encoding the TALE nuclease segregated away from the TALEN-induced mutations and was not present in some of the plants showing the mutant phenotype (Lor et al., 2014). In the same species, a CRISPR/Cas9 construct has been designed to induce loss-of-function mutations in the ARGONAUTE7 (SlAGO7) gene, which through the synthesis of short interfering RNAs causes post-transcriptional silencing of AUXIN RESPONSE FACTOR genes and regulates organ polarity (Brooks et al., 2014). Forty-eight percent of $\mathrm{T}_{0}$ transformed plants showed the expected phenotype with needle-like or wiry leaves. Only one regenerant, however, contained the deletion of the expected size after the contemporary use of two single guide RNAs (sgRNAs), the remaining being homozygous, biallelic or chimeric for small insertions and deletions. Induced mutations could be transmitted through the germline and the loss of the Cas9 transgene was shown in some progenies. A similar approach has been used in the same work to carry out functional studies in three homologs of the gene Solyc11g064850 involved in multiple aspects of tomato reproductive development. CRISPR/Cas has also been used in functional studies aiming to understand, in a hairy root tissue culture system, the role of the tomato homolog of the transcription factor SHORT-ROOT (SHR), which in Arabidopsis is known to regulate the expression of another transcription factor (SCARECROW, SCR) and induce a short root phenotype (Ron et al., 2014). Three regions of the tomato RIN gene, encoding a MADS-box transcription factor regulating fruit ripening, have also been recently targeted for inducing sequence-specific mutations by NHEJ. A range of indel mutations have been detected already in $\mathrm{T}_{0}$ plants in homozygous, heterozygous, biallelic or chimeric condition. Homozygous plants for the desired mutation have been easily recovered in following generation and some $\mathrm{T}_{1}$ plants did not carry any T-DNA. Induced mutations provoked either the formation of a truncated RIN protein or no protein accumulation, affecting fruit ripening in a variety of modes. Differently from the conventional rin mutation, however, no other genes were affected (Ito et al., 2015). Recently, the CRISPR/Cas9 system has been utilized to inactivate two genes, $s p 5 g$ (self-pruning $5 g$ ) and $s p$ (self-pruning), involved in photoperiod response, flowering and control of determinate growth. Regardless of day length, "double-determinate CR-sp/sp5g plants" showed an earlier burst of flowering and earliness for fruit set when compared to indeterminate and determinate $s p$-classic controls (Soyk et al., 2017). Alternatively to frameshift mutations determined by imprecise NHEJ repair pathway, Cermak et al. (2015) pursued in tomato the precise insertion by homologous recombination (HR) of the strong constitutive promoter $35 \mathrm{~S}$ upstream of endogenous
ANT1, which encodes a Myb transcription factor and induces anthocyanin accumulation in purple tissues. Besides the $35 \mathrm{~S}$ promoter and flanking recombination sequences, however, the donor template had to include a nptII gene for the selection of transformed cells. In order to increase template production in plant cells and gene targeting (GT) frequency, template and nuclease sequences (either TALEN or CRISPR/Cas9) have been cloned in place of endogenous viral genes encoding coat and movement proteins in a modified Bean Yellow Dwarf Virus (BeYDV) genome. As in previous reports in tomato, DNA delivery in plant cells has been accomplished by Agrobacteriummediated transformation of cotyledon explants. By employing non-integrating geminivirus replicons GT frequency achieved by TALEN and CRISPR/Cas9 systems was comparable and about one order of magnitude higher than using non-replicating T-DNA vectors. Furthermore, no off-target mutations could be detected.

In B. oleracea, CRISPR/Cas9 has been used to induce indel mutations in two regions of the BolC.GA4.a gene, which similarly to the homolog GA4 gene in Arabidopsis, is involved in gibberellin biosynthesis (Lawrenson et al., 2015). Regenerated plants showed a range of mutations in the target gene and two of them exhibited also the expected dwarf phenotype and alterations in pod valve margins. Some off-target mutations have been detected in another gene (BolC.GA4.b) which, compared with the GA4.a gene, showed two mismatches in target region 2 (no off-targeting, however, has been detected in target region 1 with four mismatches).

An alternative innovative approach for delivering editing reagents in plant cells has been recently reported in a number of species, including lettuce (Woo et al., 2015). In the latter, the homolog of the Arabidopsis BRASSINOSTEROID INSENSITIVE 2 (BIN2) gene, encoding a negative regulator in the brassinosteroid (BR) signaling pathway, has been knockedout after transfecting PEG-treated protoplasts with a mixture of Cas9 and a sgRNA targeting the third exon of the gene. Overall mutation frequency in protoplast-derived calli was $\sim 46 \%: 5.7$ and $40 \%$ of calli contained monoallelic and biallelic mutations at the target site, respectively. No off-target mutations were detected and plants regenerated via organogenesis from mutant calli transmitted the mutations to the progeny.

Finally, the virus resistance of cucumber plants has been investigated after mutating the Eukaryotic translation initiation factor $4 \mathrm{E}(e I F 4 E)$ gene in two sites: in the first case, the gene was completely knocked-down, whereas, in the second, translation of two-thirds of the protein product was still possible (Chandrasekaran et al., 2016). Chimeric $\mathrm{T}_{0}$ plants containing indel and SNP mutations were regenerated and $\mathrm{T}_{3}$ progenies were submitted to virus tests. Non-transgenic homozygous mutant plants showed either immunity or resistance to Cucumber vein yellowing virus (CVYV), Zucchini yellow mosaic virus (ZYMV), and Papaya ring spot mosaic virus$W$ (PRSV-W), although resistance breaking was observed in some cases. The same plants had no resistance to Cucumber mosaic virus (CMV) and Cucumber green mottle mosaic virus (CGMMV). After specific analyses, no off-target activity could be detected. 


\section{CONCLUSION AND PERSPECTIVES}

Vegetables include a broad number of species with different reproductive features and genetic structures, which largely affect the access to and the exploitation of genetic variability as well as the efficiency of breeding efforts. In the past decades, genetic improvement programs relied on the selection of superior families or plants from intra-specific or inter-specific crossderived populations, involving the combination of favorable traits from different genetic backgrounds. The low efficiency of phenotypic selection, especially for quantitatively inherited agronomic traits, has been overcome by the introduction of molecular marker technologies that have improved the efficiency of selection, allowing the detection of specific regions and/or genes to introgress via MAB (marker assisted breeding) programs. These approaches, however, are not free from limitations due to the large number of crosses and derived plants to manage. Artificial mutagenesis, developed in the ' 60 , allowed to increase the range of variability available for direct or indirect use, with beneficial effects particularly in vegetatively propagated crops, but the necessity to recover the desirable trait in very large populations composed of plants carrying also many undesirable mutations limits its use.

Priorities in the development of novel vegetable cultivars include the improvement of quality traits, the introduction of resistance to a broad range of pests and pathogens, and tolerance to abiotic stresses such as drought, salinity, and low/high temperature. Most of these resistance/tolerance traits need often to be transferred from wild germplasm, taking many generations to remove the deleterious genes that go along with the desirable traits due to linkage drag (Bai and Lindhout, 2007). In some cases, genes are in secondary or tertiary gene pools requiring tissue culture and/or cytogenetic manipulations in order to obtain fertile hybrids and offsprings. Furthermore, the polygenic nature of many agricultural and biochemical characters warrants the development of extensive trial populations and appropriate experimental designs for the identification of the underlying genes.

Genome editing approaches, aiming to either functional studies or genetic improvement, help face some of the abovementioned issues and allow to overcome some limitations of classical breeding (Abdallah et al., 2015; Nogue et al., 2016; Rani et al., 2016) (Figure 2). The possibility to easily recover in regenerated plants or first generation progenies homozygous/biallelic mutations induced by targeted mutagenesis or other editing approaches will ease the production of novel sets of parental lines to be used in $\mathrm{F}_{1}$ hybrid production. An additional advantage consists in the possibility to produce modified plants eventually non-transgenic, by expressing editing reagents transiently or inducing sorting-out of transgenic sequences by segregation or by the use of recombinases (Wang Y. et al., 2011; Mahfouz et al., 2016). The possibility to use genome editing tools either to achieve the crop ideotype by modifying major genes underlying key vegetative and reproductive traits, or induce the de novo domestication of wild relatives by manipulating monogenic yield-related traits, has been recently exemplified in tomato (Zsögön et al., 2017).
In the last 20 years, several efforts have been made to achieve precise targeted mutagenesis and gene insertion in higher plants, but only the development of site directed nucleases, especially the CRISPR/Cas system, has allowed a more widespread use of such approaches (Cardi and Stewart, 2016). Nevertheless, compared to cereals and other major crops (e.g., potato or oilseed rape), their application is still limited to few vegetable crops and traits. Besides regulatory and patenting issues, that will be hopefully sorted out in a near future (Egelie et al., 2016; Schinkel and Schillberg, 2016; Sprink et al., 2016), major limiting factors for a more common application of genome editing to cultivated vegetable genotypes include the availability of genomic information as well as of efficient protocols for transformation and regeneration. Furthermore, genome editing components have to be efficiently delivered into plant cells and, in case of modifications via HDR, frequency of HR optimized (Voytas, 2013; Altpeter et al., 2016; Steinert et al., 2016).

Whole genome sequences of many vegetable crops are already available, while allele mining efforts, based on whole genome resequencing and/or targeted resequencing of a fairly large number of accessions, are underway to search out valuable allelic variants in landraces and crop wild relatives. These efforts are generally paralleled by GWAS that are revealing a series of novel marker/trait associations. All such sequence-based knowledge is an essential prerequisite to transfer technologically advanced methods to vegetable species, allowing overcoming the barriers to a more widespread use of new technologies. Indeed, the possibility to use genome editing approaches to selectively knockout target genes or induce specific mutations is also effective to understand gene functions.

Although efficient ways to deliver editing reagents in plant cells must be still achieved in most crops (Ledford, 2016), it can be envisaged that in vegetables with substantial information on gene sequence and function as well as good regeneration/transformation potential (e.g., tomato, eggplant, lettuce), a range of editing approaches including gene knockout, gene editing or gene replacement/stacking can be applied soon to induce recessive or dominant novel traits. On the other hand, in cases where tissue culture and/or genomic resources are available but still not optimal, applications of genome editing will be likely limited to the introduction of (recessive) frameshift mutations in target genes, for instance those encoding negative regulators or factors necessary for essential pathogen functions [susceptibility (S) genes] (van Schie and Takken, 2014; Sun et al., 2016). In addition, provided that information on regulatory sequences are available, modified CRISPR/Cas9 complexes can be used to mediate the transcriptional activation/repression of the expression of endogenous genes (Piatek and Mahfouz, 2016). In case transformation and/or regeneration protocols are lacking in cultivated genotypes of interest, genome editing approaches can be applied to selected genotypes with good transformation/regeneration ability in order to introduce relevant mutations in the primary gene pool and subsequently transfer them by conventional means. Nevertheless, in some important vegetables (e.g., artichoke, pepper, legumes) it seems necessary to focus on the development of repeatable regeneration/transformation protocols. 


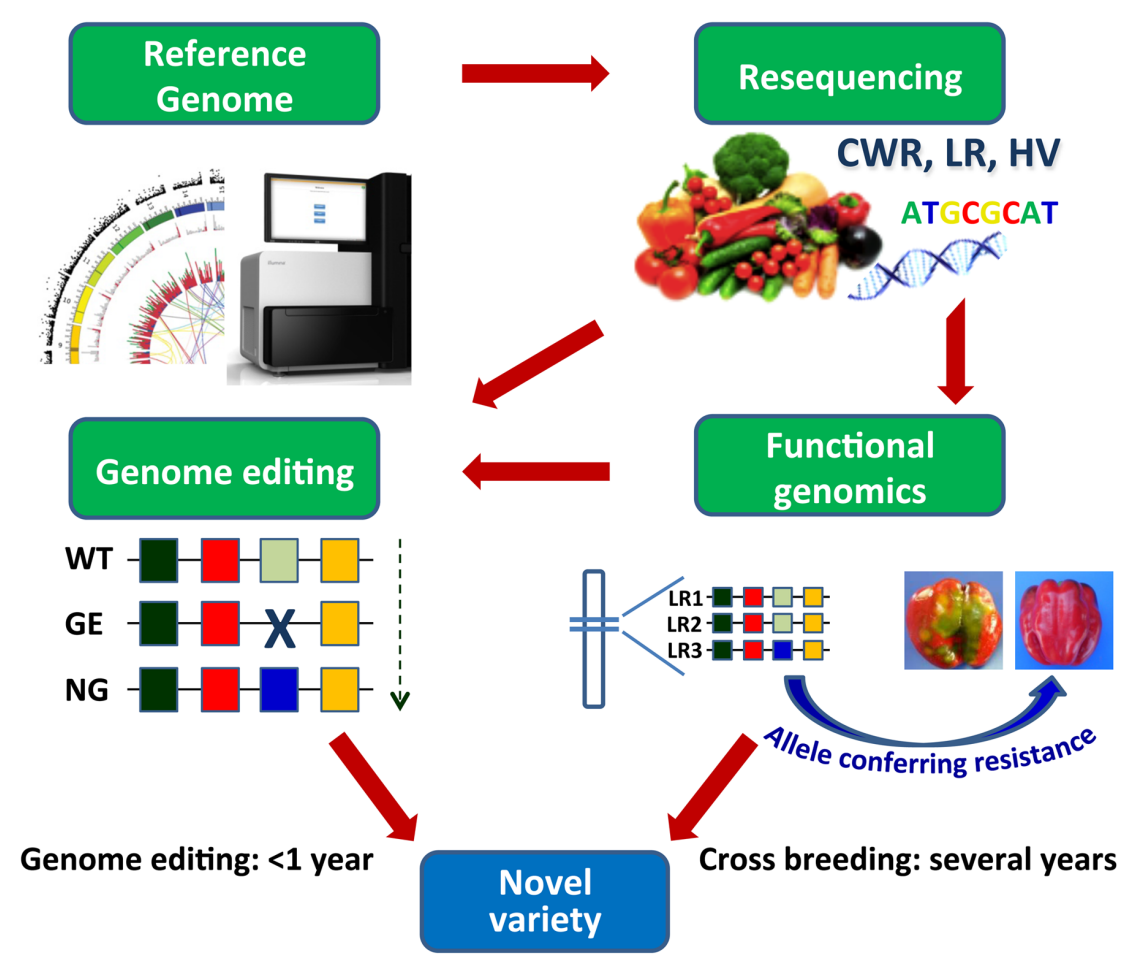

FIGURE 2 | Development and exploitation of genomic resources by cross breeding and by genome editing. Resequencing of CWR, LR, and heirloom varieties $(\mathrm{HV})$ in vegetables and subsequent identification of the allelic variation associated to relevant traits allow to introduce precise genome modifications accelerating the breeding of novel varieties. WT, wild type; GE, genome editing process; NG, new "genome edited" genotype; LR1, 2, 3, landraces. Alleles are indicated by colored boxes.

The development of such protocols has so far largely been the result of empirical experimentation regarding gene delivery and culture parameters. As previously reported, however, the genetic control of regeneration and transformation ability has been established in various species and the transfer of responsible genes achieved in some instances. More recently, the function of a number of genes involved in genetic and epigenetic mechanisms underpinning various steps of either DNSO or SE, and their possible manipulation for improving response of recalcitrant genotypes, have been described in several reviews (Duclercq et al., 2011; Pulianmackal et al., 2014; Xu and Huang, 2014; Ikeuchi et al., 2016). Engineering the production of specific plant and bacterial proteins could also help enhance Agrobacteriummediated transformation (Gelvin, 2003; Altpeter et al., 2016). In order to increase feasibility of massive screening of edited products, an automated platform has been recently developed for transformation and genome editing using plant protoplasts (Dlugosz et al., 2016). Alternatively, transformation protocols not relying on tissue culture and in vitro regeneration should be developed in recalcitrant genotypes (Altpeter et al., 2016), but although they have been reported in several crops, as described above, their reliability and general applicability is questioned (Finer, 2010).

As far as future applications are concerned, virus resistance represents a major concern in many vegetable crops. Besides recessive resistance achieved by manipulating host genes coding for factors required by invading viruses, as previously discussed for cucumber (Chandrasekaran et al., 2016), acquisition of dominant resistance has been recently reported by expressing in Nicotiana benthamiana sgRNAs directed toward various ssDNA Geminivirus, that replicate in plant cells through an intermediate dsDNA stage and are known to affect a large number of vegetables (Zaidi et al., 2016). Results obtained with tomato yellow leaf curl virus (TYLCV) and BeYDV are particularly interesting considering their possible transfer in vegetable host species (Ali et al., 2015; Baltes et al., 2015).

To date, genome editing has been mainly focused on the control of single variants underlying qualitative traits. Quantitative variation is instead mediated by several nucleotides (QTN, quantitative trait nucleotides) with large and small effects on the phenotype. Editing quantitative traits is feasible once the availability of datasets of sequences and phenotypes will enable to discover large numbers of QTNs (Jenko et al., 2015). A possible future achievement could be to perform a small number of edits on few QTNs with major effects. A further constraint in vegetable breeding is the manipulation of the reproductive system (e.g., apomixis and self-incompatibility). Such traits are under the control of several candidate genes (Hand and Koltunow, 2014; Yamamoto and Nishio, 2014) and genome editing methods could facilitate the identification of their roles, enhancing the possibility to fix desirable genotypes and accelerate the breeding rate. 


\section{AUTHOR CONTRIBUTIONS}

TC, NDA, and PT conceived and wrote the manuscript. All authors read and approved the final manuscript.

\section{REFERENCES}

100 Tomato Genome Sequencing Consortium, Aflitos, S., Schijlen, E., De Jong, H., De Ridder, D., Smit, S., et al. (2014). Exploring genetic variation in the tomato (Solanum section Lycopersicon) clade by whole-genome sequencing. Plant J. 80, 136-148. doi: 10.1111/tpj.12616

Abdallah, N. A., Prakash, C. S., and Mchughen, A. G. (2015). Genome editing for crop improvement: challenges and opportunities. GM Crops Food 6, 183-205. doi: 10.1080/21645698.2015.1129937

Acquadro, A., Barchi, L., Portis, E., Mangino, G., Valentino, D., Mauromicale, G., et al. (2016). "Whole genome resequencing in Cynara cardunculus: detection of intra-specific variability," in Proceedings of the 20th EUCARPIA General Congress: Plant Breeding: the Art of Bringing Science to Life, Zürich, 334.

Ahn, Y.-K., Karna, S., Jun, T.-H., Yang, E.-Y., Lee, H.-E., Kim, J.-H., et al. (2016). Complete genome sequencing and analysis of Capsicum annuum varieties. Mol. Breed. 36:140. doi: 10.1007/s11032-016-0557-9

Ahn, Y. K., Yoon, M. K., and Jeon, J. S. (2013). Development of an efficient agrobacterium-mediated transformation system and production of herbicideresistant transgenic plants in garlic (Allium sativum L.). Mol. Cells 36, 158-162. doi: 10.1007/s10059-013-0142-6

Ali, Z., Abulfaraj, A., Idris, A., Ali, S., Tashkandi, M., and Mahfouz, M. M. (2015). CRISPR/Cas9-mediated viral interference in plants. Genome Biol. 16:238. doi: 10.1186/s13059-015-0799-6

Altpeter, F., Springer, N. M., Bartley, L. E., Blechl, A. E., Brutnell, T. P., Citovsky, V., et al. (2016). Advancing crop transformation in the era of genome editing. Plant Cell 28, 1510-1520. doi: 10.1105/tpc.16.00196

Anderson, P. K., Cunningham, A. A., Patel, N. G., Morales, F. J., Epstein, P. R., and Daszak, P. (2004). Emerging infectious diseases of plants: pathogen pollution, climate change and agrotechnology drivers. Trends Ecol. Evol. 19, 535-544. doi: 10.1016/j.tree.2004.07.021

Anzidei, M., Bennici, A., Schiff, S., Tani, C., and Mori, B. (2000). Organogenesis and somatic embryogenesis in Foeniculum vulgare: histological observations of developing embryogenic callus. Plant Cell Tissue Organ Cult. 61, 69-79. doi: 10.1023/A:1006454702620

Aragão, F. J. L., and Campos, F. A. P. (2007). "Common bean and cowpea," in Transgenic Crops IV, eds E.-C. Pua and M. R. Davey (Heidelberg: Springer Berlin Heidelberg), 263-276. doi: 10.1007/978-3-540-36752-9_14

Aswath, C. R., Mo, S. Y., Kim, D. H., and Park, S. W. (2006). Agrobacterium and biolistic transformation of onion using non-antibiotic selection marker phosphomannose isomerase. Plant Cell Rep. 25, 92-99. doi: 10.1007/s00299005-0022-4

Bai, Y., and Lindhout, P. (2007). Domestication and breeding of tomatoes: what have we gained and what can we gain in the future? Ann. Bot. 100, 1085-1094. doi: $10.1093 / \mathrm{aob} / \mathrm{mcm} 150$

Bakshi, S., Saha, B., Roy, N. K., Mishra, S., Panda, S. K., and Sahoo, L. (2012). Successful recovery of transgenic cowpea (Vigna unguiculata) using the 6phosphomannose isomerase gene as the selectable marker. Plant Cell Rep. 31, 1093-1103. doi: 10.1007/s00299-012-1230-3

Bakshi, S., and Sahoo, L. (2013). How relevant is recalcitrance for the recovery of transgenic cowpea: implications of selection strategies. J. Plant Growth Regul. 32, 148-158. doi: 10.1007/s00344-012-9284-6

Baltes, N. J., Hummel, A. W., Konecna, E., Cegan, R., Bruns, A. N., Bisaro, D. M., et al. (2015). Conferring resistance to geminiviruses with the CRISPR-Cas prokaryotic immune system. Nat. Plants 1:15145. doi: 10.1038/nplants.2015.145

Baranski, R. (2008). Genetic transformation of carrot (Daucus carota) and other Apiaceae species. Transgenic Plant J. 2, 18-38.

Barchi, L., Delledonne, M., Lanteri, S., Dal Molin, A., Minio, A., Ferrarini, A., et al. (2016). "A high quality eggplant genome sequence: a new tool for the analysis of Solanaceae family evolution and for the molecular deciphering of complex traits," in Proceedings of the 20th EUCARPIA General Congress, Zurich.

\section{FUNDING}

This work was supported by the Italian Ministry of Agriculture, Food and Forestry (Project PEPIC).

Barraza, A., Cabrera-Ponce, J. L., Gamboa-Becerra, R., Luna-Martinez, F., Winkler, R., and Alvarez-Venegas, R. (2015). The Phaseolus vulgaris PvTRX1h gene regulates plant hormone biosynthesis in embryogenic callus from common bean. Front. Plant Sci. 6:577. doi: 10.3389/fpls.2015. 00577

Baskaran, P., Soós, V., Balázs, E., and Van Staden, J. (2016). Shoot apical meristem injection: a novel and efficient method to obtain transformed cucumber plants. S. Afr. J. Bot. 103, 210-215. doi: 10.1016/j.sajb.2015.09.006

Bezirganoglu, I., Hwang, S. Y., Shaw, J. F., and Fang, T. J. (2014). Efficient production of transgenic melon via Agrobacterium-mediated transformation. Genet. Mol. Res. 13, 3218-3227. doi: 10.4238/2014.April.25.7

Bolger, A., Scossa, F., Bolger, M. E., Lanz, C., Maumus, F., Tohge, T., et al. (2014). The genome of the stress-tolerant wild tomato species Solanum pennellii. Nat. Genet. 46, 1034-1038. doi: 10.1038/ng.3046

Brooks, C., Nekrasov, V., Lippman, Z. B., and Van Eck, J. (2014). Efficient gene editing in tomato in the first generation using the clust ered regularly interspaced short palindromic repeats/CRISPR-associated9 system. Plant Physiol. 166, 1292-1297. doi: 10.1104/pp.114.247577

Cardi, T. (2016). Cisgenesis and genome editing: combining concepts and efforts for a smarter use of genetic resources in crop breeding. Plant Breed. 135, 139-147. doi: 10.1111/pbr.12345

Cardi, T., and Stewart, C. N. Jr (2016). Progress of targeted genome modification approaches in higher plants. Plant Cell Rep. 35, 1401-1416. doi: 10.1007/ s00299-016-1975-1

Cericola, F., Portis, E., Lanteri, S., Toppino, L., Barchi, L., Acciarri, N., et al. (2014). Linkage disequilibrium and genome-wide association analysis for anthocyanin pigmentation and fruit color in eggplant. BMC Genomics 15:896. doi: 10.1186/ 1471-2164-15-896

Cermak, T., Baltes, N. J., Cegan, R., Zhang, Y., and Voytas, D. F. (2015). Highfrequency, precise modification of the tomato genome. Genome Biol. 16, 232. doi: 10.1186/s13059-015-0796-9

Chandrasekaran, J., Brumin, M., Wolf, D., Leibman, D., Klap, C., Pearlsman, M., et al. (2016). Development of broad virus resistance in non-transgenic cucumber using CRISPR/Cas9 technology. Mol. Plant Pathol. 17, 1140-1153. doi: 10.1111/mpp.12375

Chen, W., Chiu, C., Liu, H., Lee, T., Cheng, J., Lin, C., et al. (1998). Gene transfer via pollen-tube pathway for anti-fusarium wilt in watermelon. Biochem. Mol. Biol. Int. 46, 1201-1209. doi: 10.1080/15216549800204762

Chin, D. P., Bao, J. H., and Mii, M. (2009). Transgenic spinach plants produced by Agrobacterium-mediated method based on the low temperature-dependent high plant regeneration ability of leaf explants. Plant Biotechnol. 26, 243-248. doi: 10.5511/plantbiotechnology.26.243

Chowrira, G. M., Akella, V., Fuerst, P. E., and Lurquin, P. F. (1996). Transgenic grain legumes obtained byin planta electroporation-mediated gene transfer. Mol. Biotechnol. 5, 85-96. doi: 10.1007/BF02789058

Cichy, K. A., Wiesinger, J. A., and Mendoza, F. A. (2015). Genetic diversity and genome-wide association analysis of cooking time in dry bean (Phaseolus vulgaris L.). Theor. Appl. Genet. 128, 1555-1567. doi: 10.1007/s00122-0152531-z

Citadin, C. T., Ibrahim, A. B., and Aragão, F. J. L. (2011). Genetic engineering in Cowpea (Vigna unguiculata): history, status and prospects. GM Crops 2, 144-149. doi: 10.4161/gmcr.2.3.18069

Curtis, I. S., and Nam, H. G. (2001). Transgenic radish (Raphanus sativus L. longipinnatus Bailey) by floral-dip method - plant development and surfactant are important in optimizing transformation efficiency. Transgenic Res. 10, 363-371. doi: 10.1023/A:1016600517293

Davey, M. R., Anthony, P., Van Hooff, P., Power, J. B., and Lowe, K. C. (2007). "Lettuce," in Biotechnology in Agriculture and Forestry. Transgenic Crops IV, eds E. C. Pua and M. R. Davey (Heidelberg: Springer-Verlag), 221-249. doi: 10.1007/978-3-540-36752-9_12 
Derks, F. H. M. (1992). Organelle Transfer by Protoplast Fusion in Solanaceae. Ph.D. thesis, Free University of Amsterdam, Amsterdam.

Desjardins, Y. (2014). "Fruit and vegetables and health: an overview," in Horticulture: Plants for People and Places, eds G. R. Dixon and D. E. Aldous (Dordrecht: Springer Science+Business Media), 965-1000. doi: 10.1007/97894-017-8560-0_2

Dewir, Y. H., Murthy, H. N., Ammar, M. H., Alghamdi, S. S., Al-Suhaibani, N. A., Alsadon, A. A., et al. (2016). In vitro rooting of leguminous plants: difficulties, alternatives, and strategies for improvement. Hortic. Environ. Biotechnol. 57, 311-322. doi: 10.1007/s13580-016-0060-6

Dlugosz, E. M., Lenaghan, S. C., and Stewart, C. N. Jr. (2016). A robotic platform for high-throughput protoplast isolation and transformation. J. Vis. Exp. 2016:e54300. doi: 10.3791/54300

Duclercq, J., Sangwan-Norreel, B., Catterou, M., and Sangwan, R. S. (2011). De novo shoot organogenesis: from art to science. Trends Plant Sci. 16, 597-606. doi: 10.1016/j.tplants.2011.08.004

Eady, C., Davis, S., Catanach, A., Kenel, F., and Hunger, S. (2005). Agrobacterium tumefaciens-mediated transformation of leek (Allium porrum) and garlic (Allium sativum). Plant Cell Rep. 24, 209-215. doi: 10.1007/s00299-005-0926-z

Eady, C. C., Weld, R. J., and Lister, C. E. (2000). Agrobacterium tumefaciensmediated transformation and transgenic-plant regeneration of onion (Allium cepa L.). Plant Cell Rep. 19, 376-381. doi: 10.1007/s002990050743

Egelie, K. J., Graff, G. D., Strand, S. P., and Johansen, B. (2016). The emerging patent landscape of CRISPR-Cas gene editing technology. Nat. Biotechnol. 34, 1025-1031. doi: 10.1038/nbt.3692

Fernandez-Pozo, N., Menda, N., Edwards, J. D., Saha, S., Tecle, I. Y., Strickler, S. R., et al. (2015). The Sol Genomics Network (SGN)-from genotype to phenotype to breeding. Nucleic Acids Res. 43, D1036-D1041. doi: 10.1093/nar/gku1195

Finer, J. J. (2010). "Plant nuclear transformation," in Genetic Modification of Plants, 1st Edn, eds F. Kempken and C. Jung (Heidelberg: Springer-Verlag), 499-550.

Finkers, R., Van Workum, W., Van Kaauwen, M., Huits, H., Jungerius, A., Vosman, B., et al. (2015). "A de novo assembly for the 16GB Allium cepa genome, tears of joy," in Proceedings of the Largest Ag-Genomics Meeting in the World: Plant \& Animal Genome XXIII, San Diego, CA.

$\mathrm{Fu}, \mathrm{N}$., Wang, Q., and Shen, H. L. (2013). De novo assembly, gene annotation and marker development using Illumina paired-end transcriptome sequences in celery (Apium graveolens L.). PLoS ONE 8:e57686. doi: 10.1371/journal.pone. 0057686

Galla, G., Chedina, A., Tiozzo, S., and Barcaccia, G. (2014). "Towards a first highquality genome draft for leaf chicory, radicchio (Cichorium intybus L.)," in Proceedings of the 58th Italian Society of Agricultural Genetics Annual Congress, Alghero.

Gantait, S., Mandal, N., and Das, P. K. (2010). An Overview on in vitro culture of genus allium. Am. J. Plant Physiol. 5, 325-337. doi: 10.3923/ajpp.2010.325.337

Garcia-Mas, J., Benjak, A., Sanseverino, W., Bourgeois, M., Mir, G., Gonzalez, V. M., et al. (2012). The genome of melon (Cucumis melo L.). Proc. Natl. Acad. Sci. U.S.A. 109, 11872-11877. doi: 10.1073/pnas.1205415109

Gatti, I., Guindón, F., Bermejo, C., Espósito, A., and Cointry, E. (2016). In vitro tissue culture in breeding programs of leguminous pulses: use and current status. Plant Cell Tissue Organ Cult. 127, 543-559. doi: 10.1007/s11240-016$1082-6$

Geekiyanage, S., Takase, T., Watanabe, S., Fukai, S., and Kiyosue, T. (2006). The combined effect of photoperiod, light intensity and $\mathrm{GA}_{3}$ on adventitious shoot regeneration from cotyledons of spinach (Spinacia oleracea L.). Plant Biotechnol. 23, 431-435. doi: 10.5511/plantbiotechnology.23.431

Gelvin, S. B. (2003). Improving plant genetic engineering by manipulating the host. Trends Biotechnol. 21, 95-98. doi: 10.1016/S0167-7799(03)00005-2

Gómez-Montes, E. O., Oliver-Salvador, C., Durán-Figueroa, N., Badillo-Corona, J. A., and Salas, C. E. (2015). Optimization of direct shoot regeneration using cotyledonary explants and true leaves from lettuce cv. Romaine (Lactuca sativa L.) by surface response methodology. Plant Growth Regul. 77, 327-334. doi: 10.1007/s10725-015-0067-5

Gonthier, L., Bellec, A., Blassiau, C., Prat, E., Helmstetter, N., Rambaud, C., et al. (2010). Construction and characterization of two BAC libraries representing a deep-coverage of the genome of chicory (Cichorium intybus L., Asteraceae). BMC Res. Notes 3:225. doi: 10.1186/1756-0500-3-225
Guo, S., Zhang, J., Sun, H., Salse, J., Lucas, W. J., Zhang, H., et al. (2013). The draft genome of watermelon (Citrullus lanatus) and resequencing of 20 diverse accessions. Nat. Genet. 45, 51-58. doi: 10.1038/ng.2470

Hand, M. L., and Koltunow, A. M. (2014). The genetic control of apomixis: asexual seed formation. Genetics 197, 441-450. doi: 10.1534/genetics.114.163105

Heidmann, I., De Lange, B., Lambalk, J., Angenent, G. C., and Boutilier, K. (2011). Efficient sweet pepper transformation mediated by the BABY BOOM transcription factor. Plant Cell Rep. 30, 1107-1115. doi: 10.1007/s00299-011$1018-\mathrm{x}$

Hirakawa, H., Shirasawa, K., Miyatake, K., Nunome, T., Negoro, S., Ohyama, A., et al. (2014). Draft genome sequence of eggplant (Solanum melongena L.): the representative solanum species indigenous to the old world. DNA Res. 21, 649-660. doi: 10.1093/dnares/dsu027

Hnatuszko-Konka, K., Kowalczyk, T., Gerszberg, A., Wiktorek-Smagur, A., and Kononowicz, A. K. (2014). Phaseolus vulgaris - Recalcitrant potential. Biotechnol. Adv. 32, 1205-1215. doi: 10.1016/j.biotechadv.2014.06.001

Huang, S., Li, R., Zhang, Z., Li, L., Gu, X., Fan, W., et al. (2009). The genome of the cucumber, Cucumis sativus L. Nat. Genet. 41, 1275-1281. doi: 10.1038/ng.475

Ikeuchi, M., Ogawa, Y., Iwase, A., and Sugimoto, K. (2016). Plant regeneration: cellular origins and molecular mechanisms. Development 143, 1442-1451. doi: $10.1242 /$ dev. 134668

Ilori, C. O., and Pellegrineschi, A. (2011). Transgene expression in cowpea (Vigna unguiculata (L.) Walp.) through Agrobacterium transformation of pollen in flower buds. Afr. J. Biotechnol. 10, 11821-11828.

Iorizzo, M., Ellison, S., Senalik, D., Zeng, P., Satapoomin, P., Huang, J., et al. (2016). A high-quality carrot genome assembly provides new insights into carotenoid accumulation and asterid genome evolution. Nat. Genet. 48, 657-666. doi: 10.1038/ng.3565

Iorizzo, M., Senalik, D. A., Ellison, S. L., Grzebelus, D., Cavagnaro, P. F. Allender, C., et al. (2013). Genetic structure and domestication of carrot (Daucus carota subsp. sativus) (Apiaceae). Am. J. Bot. 100, 930-938. doi: 10. 3732/ajb.1300055

Ito, Y., Nishizawa-Yokoi, A., Endo, M., Mikami, M., and Toki, S. (2015). CRISPR/Cas9-mediated mutagenesis of the RIN locus that regulates tomato fruit ripening. Biochem. Biophys. Res. Commun. 467, 76-82. doi: 10.1016/j.bbrc. 2015.09.117

Jakhar, M. L., and Choudhary, M. R. (2012). Regeneration of in vitro plantlets through organogenesis in fennel (Foeniculum Vulgare Mill.). J. Plant Sci. Res. 28, 203-209.

Jenko, J., Gorjanc, G., Cleveland, M. A., Varshney, R. K., Whitelaw, C. B., Woolliams, J. A., et al. (2015). Potential of promotion of alleles by genome editing to improve quantitative traits in livestock breeding programs. Genet. Sel. Evol. 47, 55 doi: 10.1186/s12711-015-0135-3

Kamfwa, K., Cichy, K. A., and Kelly, J. D. (2015). Genome-wide association analysis of symbiotic nitrogen fixation in common bean. Theor. Appl. Genet. 128, 1999-2017. doi: 10.1007/s00122-015-2562-5

Kaur, S., Pembleton, L. W., Cogan, N. O., Savin, K. W., Leonforte, T., Paull, J., et al. (2012). Transcriptome sequencing of field pea and faba bean for discovery and validation of SSR genetic markers. BMC Genomics 13:104. doi: 10.1186/14712164-13-104

Kenel, F., Eady, C., and Brinch, S. (2010). Efficient Agrobacterium tumefaciensmediated transformation and regeneration of garlic (Allium sativum) immature leaf tissue. Plant Cell Rep. 29, 223-230. doi: 10.1007/s00299-009-0814-z

Kim, S., Park, M., Yeom, S. I., Kim, Y. M., Lee, J. M., Lee, H. A., et al. (2014). Genome sequence of the hot pepper provides insights into the evolution of pungency in Capsicum species. Nat. Genet. 46, 270-278. doi: 10.1038/ng.2877

Kitashiba, H., Li, F., Hirakawa, H., Kawanabe, T., Zou, Z., Hasegawa, Y., et al. (2014). Draft sequences of the radish (Raphanus sativus L.) genome. DNA Res. 21, 481-490. doi: 10.1093/dnares/dsu014

Klenotičová, H., Smykalová, I., Švábová, L., and Griga, M. (2013). Resolving browning during the establishment of explant cultures in Vicia faba L. for genetic transformation. Acta Univ. Agric. Silvic. Mendel. Brun. 61, 1279-1288. doi: 10.11118/actaun201361051279

Klocke, E., Nothnagel, T., and Schumann, G. (2010). "Vegetables," in Genetic Modification of Plants, 1st Edn, eds F. Kempken and C. Jung (Heidelberg: Springer-Verlag). 
Koornneef, M., Bade, J., Hanhart, C., Horsman, K., Schel, J., Soppe, W., et al. (1993). Characterization and mapping of a gene controlling shoot regeneration in tomato. Plant J. 3, 131-141. doi: 10.1111/j.1365-313X.1993.tb00016.x

Kothari, S. L., Joshi, A., Kachhwaha, S., and Ochoa-Alejo, N. (2010). Chilli peppersa review on tissue culture and transgenesis. Biotechnol. Adv. 28, 35-48. doi: 10.1016/j.biotechadv.2009.08.005

Kumar, P., and Srivastava, D. K. (2016). Biotechnological advancement in genetic improvement of broccoli (Brassica oleracea L. var. italica), an important vegetable crop. Biotechnol. Lett. 38, 1049-1063. doi: 10.1007/s10529-0162080-9

Kurtz, S. M., and Lineberger, R. D. (1983). Genotypic differences in morphogenic capacity of cultured leaf explants of tomato [Lycopersicon esculentum]. J. Am. Soc. Hortic. Sci. 108, 710-714.

Lawrenson, T., Shorinola, O., Stacey, N., Li, C., Ostergaard, L., Patron, N., et al. (2015). Induction of targeted, heritable mutations in barley and Brassica oleracea using RNA-guided Cas9 nuclease. Genome Biol. 16, 258. doi: 10.1186/ s13059-015-0826-7

Ledford, H. (2016). A better way to hack plant DNA. Nature 539, 16-17. doi: $10.1038 / 539016 \mathrm{a}$

Li, S. F., Gao, W. J., Zhao, X. P., Dong, T. Y., Deng, C. L., and Lu, L. D. (2014). Analysis of transposable elements in the genome of Asparagus officinalis from high coverage sequence data. PLoS ONE 9:e97189. doi: 10.1371/journal.pone. 0097189

Lin, K., Zhang, N., Severing, E. I., Nijveen, H., Cheng, F., Visser, R. G., et al. (2014). Beyond genomic variation-comparison and functional annotation of three Brassica rapa genomes: a turnip, a rapid cycling and a Chinese cabbage. BMC Genomics 15:250. doi: 10.1186/1471-2164-15-250

Lin, T., Zhu, G., Zhang, J., Xu, X., Yu, Q., Zheng, Z., et al. (2014). Genomic analyses provide insights into the history of tomato breeding. Nat. Genet. 46, 1220-1226. doi: 10.1038/ng.3117

Liu, L., Gu, Q., Ijaz, R., Zhang, J., and Ye, Z. (2016). Generation of transgenic watermelon resistance to Cucumber mosaic virus facilitated by an effective Agrobacterium-mediated transformation method. Sci. Hortic. 205, 32-38. doi: 10.1016/j.scienta.2016.04.013

Liu, S., Liu, Y., Yang, X., Tong, C., Edwards, D., Parkin, I. A., et al. (2014). The Brassica oleracea genome reveals the asymmetrical evolution of polyploid genomes. Nat. Commun. 5:3930. doi: 10.1038/ncomms4930

Liu, Z., Park, B.-J., Kanno, A., and Kameya, T. (2005). The novel use of a combination of sonication and vacuum infiltration in Agrobacterium-mediated transformation of kidney bean (Phaseolus vulgaris L.) with lea gene. Mol. Breed. $16,189$.

Lombardi-Crestana, S., Azevedo, M. D., Silva, G. F. F. E., Pino, L. E., AppezzatoDa-Gloria, B., Figueira, A., et al. (2012). The tomato (Solanum lycopersicum cv. Micro-Tom) natural genetic variation Rg1 and the DELLA mutant procera control the competence necessary to form adventitious roots and shoots. J. Exp. Bot. 63, 5689-5703. doi: 10.1093/jxb/ers221

Lor, V. S., Starker, C. G., Voytas, D. F., Weiss, D., and Olszewski, N. E. (2014). Targeted mutagenesis of the tomato PROCERA gene using transcription activator-like effector nucleases. Plant Physiol. 166, 1288-1291. doi: 10.1104/ pp.114.247593

Macas, J., Neumann, P., and Navratilova, A. (2007). Repetitive DNA in the pea (Pisum sativum L.) genome: comprehensive characterization using 454 sequencing and comparison to soybean and Medicago truncatula. BMC Genomics 8:427. doi: 10.1186/1471-2164-8-427

Maggioni, L. (2004). "Conservation and use of vegetable genetic resources: a european perspective," in Proceedings of the International Society for Horticultural Science (ISHS), Leuven, 13-30. doi: 10.17660/actahortic.2004. 637.1

Mahfouz, M. M., Cardi, T., and Neal Stewart, C. Jr (2016). Next-generation precision genome engineering and plant biotechnology. Plant Cell Rep. 35, 1397-1399. doi: 10.1007/s00299-016-2009-8

Manamohan, M., Prakash, N., and Sharath Chandra, G. (2011). "Cucurbits," in Advances in Horticulture Biotechnology, eds K. Nirmal Babu, H. P. Singh, and V. A. Parthasarathy (New Delhi: Westville Publishing House), $227-252$.

Matvieieva, N. A. (2015). Agrobacterium-mediated transformation of compositae plants. I. Construction of transgenic plants and "hairy" roots with new properties. Biotechnol. Acta 8, 19-31. doi: 10.15407/biotech8.01.019
Menin, B., Moglia, A., Comino, C., Lanteri, S., Van Herpen, T. W. J. M., and Beekwilder, J. (2012). "In vitro callogenesis and Agrobacterium-mediated transformation of globe artichoke," in Proceedings of the International Society for Horticultural Science (ISHS), Leuven, 267-271. doi: 10.17660/actahortic.2012. 961.34

Michael, T. P., and VanBuren, R. (2015). Progress, challenges and the future of crop genomes. Curr. Opin. Plant Biol. 24, 71-81. doi: 10.1016/j.pbi.2015. 02.002

Mikschofsky, H., and Broer, I. (2012). Feasibility of Pisum sativum as an expression system for pharmaceuticals. Transgenic Res. 21 , 715-724. doi: 10.1007/s11248011-9573-z

Milojević, J., Tubić, L., Nolić, V., Mitić, N., Ćalić-Dragosavac, D., Vinterhalter, B., et al. (2012). Hygromycin promotes somatic embryogenesis in spinach. Plant Cell Tissue Organ Cult. 109, 573-579. doi: 10.1007/s11248-011-9573-z

Nadolska-Orczyk, A., and Malepszy, S. (1989). In vitro culture of Cucumis sativus L. Theor. Appl. Genet. 78, 836-840. doi: 10.1007/BF00266667

Nanasato, Y., Okuzaki, A., and Tabei, Y. (2013). Improving the transformation efficiency of Cucurbita species: factors and strategy for practical application. Plant Biotechnol. 30, 287-294. doi: 10.5511/plantbiotechnology.13.0331a

Nguyen, A. H., Hodgson, L. M., Erskine, W., and Barker, S. J. (2016). An approach to overcoming regeneration recalcitrance in genetic transformation of lupins and other legumes. Plant Cell Tissue Organ Cult. 127, 623-635. doi: 10.1007/ s11240-016-1087-1

Nguyen, Q. V., Boo, K. H., Sun, H. J., Cao, D. V., Lee, D., Ko, S. H., et al. (2013a). Evaluation of factors influencing Agrobacterium-mediated spinach transformation and transformant selection by EGFP fluorescence under lowselective pressure. In vitro Cell. Dev. Biol. Plant 49, 498-509. doi: 10.1007/ s11627-013-9534-8

Nguyen, Q. V., Sun, H. J., Boo, K. H., Lee, D., Lee, J.-H., Lim, P. O., et al. (2013b). Effect of plant growth regulator combination and culture period on in vitro regeneration of spinach (Spinacia oleracea L.). Plant Biotechnol. Rep. 7, 99-108. doi: $10.1007 / \mathrm{s} 11816-012-0242-3$

Nimmakayala, P., Abburi, V. L., Saminathan, T., Almeida, A., Davenport, B., Davidson, J., et al. (2016a). Genome-wide divergence and linkage disequilibrium analyses for Capsicum baccatum revealed by genomeanchored single nucleotide polymorphisms. Front. Plant Sci. 7:1646. doi: 10.3389/fpls.2016.01646

Nimmakayala, P., Levi, A., Abburi, L., Abburi, V. L., Tomason, Y. R., Saminathan, T., et al. (2014). Single nucleotide polymorphisms generated by genotyping by sequencing to characterize genome-wide diversity, linkage disequilibrium, and selective sweeps in cultivated watermelon. BMC Genomics 15:767. doi: 10.1186/1471-2164-15-767

Nimmakayala, P., Tomason, Y. R., Abburi, V. L., Alvarado, A., Saminathan, T., Vajja, V. G., et al. (2016b). Genome-wide differentiation of various melon horticultural groups for use in GWAS for fruit firmness and construction of a high resolution genetic map. Front. Plant Sci. 7:1437.

Nogue, F., Mara, K., Collonnier, C., and Casacuberta, J. M. (2016). Genome engineering and plant breeding: impact on trait discovery and development. Plant Cell Rep. 35, 1475-1486. doi: 10.1007/s00299-016-1993-z

O'Sullivan, D. M., and Angra, D. (2016). Advances in faba bean genetics and genomics. Front. Genet. 7:150. doi: 10.3389/fgene.2016.00150

Park, J.-I., Ahmed, N. U., Kim, H.-R., and Nou, I.-S. (2012). Advances in in vitro culture of the Brassicaceae crop plants. J. Plant Biotechnol. 39, 13-22. doi: 10.1007/978-1-4939-1695-5\_23

Perseguini, J. M., Oblessuc, P. R., Rosa, J. R., Gomes, K. A., Chiorato, A. F., Carbonell, S. A., et al. (2016). Genome-wide association studies of anthracnose and angular leaf spot resistance in common bean (Phaseolus vulgaris L.). PLoS ONE 11:e0150506. doi: 10.1371/journal.pone.0150506

Piatek, A., and Mahfouz, M. M. (2016). Targeted genome regulation via synthetic programmable transcriptional regulators. Crit. Rev. Biotechnol. doi: 10.3109/ 07388551.2016.1165180 [Epub ahead of print].

Pino, L. E., Lombardi-Crestana, S., Azevedo, M. S., Scotton, D. C., Borgo, L., Quecini, V., et al. (2010). The Rg1 allele as a valuable tool for genetic transformation of the tomato 'Micro-Tom' model system. Plant Methods 6:23. doi: 10.1186/1746-4811-6-23

Portis, E., Cericola, F., Barchi, L., Toppino, L., Acciarri, N., Pulcini, L., et al. (2015). Association mapping for fruit, plant and leaf morphology traits in eggplant. PLoS ONE 10:e0135200. doi: 10.1371/journal.pone.0135200 
Pulianmackal, A. J., Kareem, A. V., Durgaprasad, K., Trivedi, Z. B., and Prasad, K. (2014). Competence and regulatory interactions during regeneration in plants. Front. Plant Sci. 5:142. doi: 10.3389/fpls.2014.00142

Punja, Z. K., Jayaraj, J., and Wally, O. (2007). "Carrot," in Biotechnology in Agriculture and Forestry. Transgenic Crops IV, eds E. C. Pua and M. R. Davey (Heidelberg: Springer-Verlag), 277-294. doi: 10.1007/978-3-540-36752-9_15

Qin, C., Yu, C., Shen, Y., Fang, X., Chen, L., Min, J., et al. (2014). Whole-genome sequencing of cultivated and wild peppers provides insights into Capsicum domestication and specialization. Proc. Natl. Acad. Sci. U.S.A. 111, 5135-5140. doi: 10.1073/pnas.1400975111

Ranc, N., Munos, S., Xu, J., Le Paslier, M. C., Chauveau, A., Bounon, R., et al. (2012). Genome-wide association mapping in tomato (Solanum lycopersicum) is possible using genome admixture of Solanum lycopersicum var. cerasiforme. G3 (Bethesda) 2, 853-864. doi: 10.1534/g3.112.002667

Rani, R., Yadav, P., Barbadikar, K. M., Baliyan, N., Malhotra, E. V., Singh, B. K., et al. (2016). CRISPR/Cas9: a promising way to exploit genetic variation in plants. Biotechnol. Lett. 38, 1991-2006. doi: 10.1007/s10529-016-2195-z

Ron, M., Kajala, K., Pauluzzi, G., Wang, D., Reynoso, M. A., Zumstein, K., et al. (2014). Hairy root transformation using Agrobacterium rhizogenes as a tool for exploring cell type-specific gene expression and function using tomato as a model. Plant Physiol. 166, 455-469. doi: 10.1104/pp.114.239392

Rotino, G. L., Sala, T., and Toppino, L. (2014). "Eggplant," in Alien Gene Transfer in Crop Plants, 1st Edn, Vol. 2, eds A. Pratap and J. Kumar (New York, NY: Springer-Verlag).

Ruggieri, V., Francese, G., Sacco, A., D’alessandro, A., Rigano, M. M., Parisi, M., et al. (2014). An association mapping approach to identify favourable alleles for tomato fruit quality breeding. BMC Plant Biol. 14:337. doi: 10.1186/s12870014-0337-9

Sauvage, C., Segura, V., Bauchet, G., Stevens, R., Do, P. T., Nikoloski, Z., et al. (2014). Genome-wide association in tomato reveals 44 candidate loci for fruit metabolic traits. Plant Physiol. 165, 1120-1132. doi: 10.1104/pp.114.241521

Saxena, S. N., Kothari, P., Rathore, S. S., Ishan-Ulla-Khan, and Saxena, R. (2012). Organogenesis in fennel (Foeniculum vulgare Mill.). Int. J. Seed Spices 2, 1-4.

Scaglione, D., Lanteri, S., Acquadro, A., Lai, Z., Knapp, S. J., Rieseberg, L., et al. (2012). Large-scale transcriptome characterization and mass discovery of SNPs in globe artichoke and its related taxa. Plant Biotechnol. J. 10, 956-969. doi: 10.1111/j.1467-7652.2012.00725.x

Scaglione, D., Reyes-Chin-Wo, S., Acquadro, A., Froenicke, L., Portis, E., Beitel, C., et al. (2016). The genome sequence of the outbreeding globe artichoke constructed de novo incorporating a phase-aware low-pass sequencing strategy of F1 progeny. Sci. Rep. 6:19427. doi: 10.1038/srep19427

Schinkel, H., and Schillberg, S. (2016). Genome editing: intellectual property and product development in plant biotechnology. Plant Cell Rep. 35, 1487-1491. doi: 10.1007/s00299-016-1988-9

Schmutz, J., Mcclean, P. E., Mamidi, S., Wu, G. A., Cannon, S. B., Grimwood, J., et al. (2014). A reference genome for common bean and genome-wide analysis of dual domestications. Nat. Genet. 46, 707-713. doi: 10.1038/ng.3008

Shirasawa, K., Fukuoka, H., Matsunaga, H., Kobayashi, Y., Kobayashi, I., Hirakawa, H., et al. (2013). Genome-wide association studies using single nucleotide polymorphism markers developed by re-sequencing of the genomes of cultivated tomato. DNA Res. 20, 593-603. doi: 10.1093/dnares/dst033

Silva Dias, J. (2014). Guiding strategies for breeding vegetable cultivars. Agric. Sci. 5, 9-32. doi: 10.4236/as.2014.51002

Solís-Ramos, L. Y., González-Estrada, T., Nahuath-Dzib, S., Zapata-Rodriguez, L. C., and Castaño, E. (2009). Overexpression of WUSCHEL in C. chinense causes ectopic morphogenesis. Plant Cell Tissue Organ Cult. 96, 279-287. doi: 10.1007/s11240-008-9485-7

Somers, D. A., Samac, D. A., and Olhoft, P. M. (2003). Recent advances in legume transformation. Plant Physiol. 131, 892-899. doi: 10.1104/pp.102. 017681

Song, D., Han, Q., Dong, Z., and He, Z. (2014). Genetic transformation of lettuce (Lactuca sativa): a review. Afr. J. Biotechnol. 13, 1686-1693. doi: 10.5897/ AJB2014.13651

Song, G.-Q., Loskutov, A. V., and Sink, K. C. (2007). Highly efficient Agrobacterium tumefaciens-mediated transformation of celery (Apium graveolens L.) through somatic embryogenesis. Plant Cell Tissue Organ Cult. 88, 193-200. doi: 10.1007/ s11240-006-9190-3
Soyk, S., Muller, N. A., Park, S. J., Schmalenbach, I., Jiang, K., Hayama, R., et al. (2017). Variation in the flowering gene SELF PRUNING 5G promotes dayneutrality and early yield in tomato. Nat. Genet. 49, 162-168. doi: 10.1038/ng. 3733

Sparrow, P. A. C., Dale, P. J., and Irwin, J. A. (2004). The use of phenotypic markers to identify Brassica oleracea genotypes for routine high-throughput Agrobacterium-mediated transformation. Plant Cell Rep. 23, 64-70. doi: 10. 1007/s00299-004-0818-7

Sparrow, P. A. C., Goldsack, C. M. P., and Østergaard, L. (2011). “Transformation technology in the Brassicaceae," in Genetics and Genomics of the Brassicaceae, eds R. Schmidt and I. Bancroft (New York, NY: Springer-Verlag), 505-525. doi: 10.1007/978-1-4419-7118-0_18

Sprink, T., Eriksson, D., Schiemann, J., and Hartung, F. (2016). Regulatory hurdles for genome editing: process- vs. product-based approaches in different regulatory contexts. Plant Cell Rep. 35, 1493-1506. doi: 10.1007/s00299-0161990-2

Steinert, J., Schiml, S., and Puchta, H. (2016). Homology-based double-strand break-induced genome engineering in plants. Plant Cell Rep. 35, 1429-1438. doi: 10.1007/s00299-016-1981-3

Sun, K., Wolters, A. M., Vossen, J. H., Rouwet, M. E., Loonen, A. E., Jacobsen, E., et al. (2016). Silencing of six susceptibility genes results in potato late blight resistance. Transgenic Res. 25, 731-742. doi: 10.1007/s11248-016-9964-2

Sun, X., Zhou, S., Meng, F., and Liu, S. (2012). De novo assembly and characterization of the garlic (Allium sativum) bud transcriptome by Illumina sequencing. Plant Cell Rep. 31, 1823-1828. doi: 10.1007/s00299-012-1295-z

Svabova, L., Smykal, P., Griga, M., and Ondrej, V. (2005). Agrobacterium-mediated transformation of Pisum sativum in vitro and in vivo. Biol. Plant. 49, 361-370. doi: 10.1007/s10535-005-0009-6

Taranto, F., D'agostino, N., Greco, B., Cardi, T., and Tripodi, P. (2016). Genomewide SNP discovery and population structure analysis in pepper (Capsicum annuum) using genotype-by-sequencing. BMC Genomics 17:943. doi: 10.1186/ s12864-016-3297-7

Terracciano, I., Cantarella, C., and D'agostino, N. (2016). "Hybridization-based enrichment and next generation sequencing to explore genetic diversity in plants," in Dynamics of Mathematical Models in Biology, eds A. Rogato, V. Zazzu, and M. R. Guarracino (Cham: Springer International Publishing).

Timko, M. P., Rushton, P. J., Laudeman, T. W., Bokowiec, M. T., Chipumuro, E., Cheung, F., et al. (2008). Sequencing and analysis of the gene-rich space of cowpea. BMC Genomics 9:103. doi: 10.1186/1471-2164-9-103

Tomato Genome Consortium (2012). The tomato genome sequence provides insights into fleshy fruit evolution. Nature 485, 635-641. doi: 10.1038/ nature 11119

Truco, M. J., Ashrafi, H., Kozik, A., Van Leeuwen, H., Bowers, J., Reyes Chin Wo, S., et al. (2013). An ultra high-density, transcript-based, genetic map of lettuce. G3 (Bethesda) 3, 617-631. doi: 10.1534/g3.112.004929

van Schie, C. C., and Takken, F. L. (2014). Susceptibility genes 101: how to be a good host. Annu. Rev. Phytopathol. 52, 551-581. doi: 10.1146/annurev-phyto102313-045854

Veltcheva, M., Svetleva, D., Petkova, S., and Perl, A. (2005). In vitro regeneration and genetic transformation of common bean (Phaseolus vulgaris L.) Problems and progress. Sci. Hortic. 107, 2-10. doi: 10.1016/j.scienta.2005. 07.005

Vinoth, A., and Ravindhran, R. (2015). Efficient plant regeneration of watermelon (Citrullus lanatus Thunb.) via somatic embryogenesis and assessment of genetic fidelity using ISSR markers. In Vitro Cell. Dev. Biol. Plant 52, 107-115. doi: 10.1007/s11627-015-9731-8

Vinterhalter, D., Sretenovič-Rajičič, T., Vinterhalter, B., and Ninkovic, S. (2007). Genetic transformation of Brassica oleracea vegetables. Transgenic Plant J. 1, 340-355.

Vlasova, A., Capella-Gutierrez, S., Rendon-Anaya, M., Hernandez-Onate, M., Minoche, A. E., Erb, I., et al. (2016). Genome and transcriptome analysis of the Mesoamerican common bean and the role of gene duplications in establishing tissue and temporal specialization of genes. Genome Biol. 17, 32. doi: 10.1186/ s13059-016-0883-6

Voytas, D. F. (2013). Plant genome engineering with sequence-specific nucleases. Annu. Rev. Plant Biol. 64, 327-350. doi: 10.1146/annurev-arplant-042811105552 
Wang, S.-L., Ku, S. S., Ye, X.-G., He, C.-F., Kwon, S. Y., and Choi, P. S. (2015). Current status of genetic transformation technology developed in cucumber (Cucumis sativus L.). J. Integr. Agric. 14, 469-482. doi: 10.1016/S2095-3119(14) 60899-6

Wang, X., Wang, H., Wang, J., Sun, R., Wu, J., Liu, S., et al. (2011). The genome of the mesopolyploid crop species Brassica rapa. Nat. Genet. 43, 1035-1039. doi: 10.1038/ng.919

Wang, Y., Yau, Y. Y., Perkins-Balding, D., and Thomson, J. G. (2011). Recombinase technology: applications and possibilities. Plant Cell Rep. 30, 267-285. doi: 10.1007/s00299-010-0938-1

Wędzony, M., Szechyńska-Hebda, M., Żur, I., Dubas, E., and Krzewska, M. (2014). "Tissue culture and regeneration: a prerequisite for alien gene transfer," in Alien Gene Transfer in Crop Plants: Innovations, Methods and Risk Assessment, Vol. 1, eds A. Pratap and J. Kumar (New York, NY: Springer), 43-75.

Woo, J. W., Kim, J., Kwon, S. I., Corvalan, C., Cho, S. W., Kim, H., et al. (2015). DNA-free genome editing in plants with preassembled CRISPRCas9 ribonucleoproteins. Nat. Biotechnol. 33, 1162-1164. doi: 10.1038/nbt. 3389

Xu, L., and Huang, H. (2014). "Chapter One - Genetic and epigenetic controls of plant regeneration," in Current Topics in Developmental Biology, ed. G. Brigitte (Cambridge, MA: Academic Press), 1-33.

Yamamoto, M., and Nishio, T. (2014). Commonalities and differences between Brassica and Arabidopsis self-incompatibility. Hortic. Res. 1, 14054. doi: 10. 1038/hortres.2014.54

Zaidi, S., Tashkandi, M., Mansoor, S., and Mahfouz, M. (2016). Engineering plant immunity: using CRISPR/Cas9 to generate virus resistance. Front. Plant Sci. 7:1673. doi: 10.3389/fpls.2016.01673

Zhang, H., Gao, P., Wang, X., and Luan, F. (2014). An improved method of Agrobacterium tumefaciens-mediated genetic transformation system of melon (Cucumis melo L.). J. Plant Biochem. Biotechnol. 23, 278-283. doi: 10.1007/ s13562-013-0211-0
Zhang, J., Zhao, J., Xu, Y., Liang, J., Chang, P., Yan, F., et al. (2015). Genomewide association mapping for tomato volatiles positively contributing to tomato flavor. Front. Plant Sci. 6:1042. doi: 10.3389/fpls.2015. 01042

Zhang, N., Huang, X., Bao, Y., Wang, B., Liu, L., Dai, L., et al. (2015). Genomewide identification and expression profiling of WUSCHEL-related homeobox (WOX) genes during adventitious shoot regeneration of watermelon (Citrullus lanatus). Acta Physiol. Plant. 37, 224. doi: 10.1007/s11738-015-1964-y

Zheng, S.-J., Henken, B., Kyun Ahn, Y., Krens, F. A., and Kik, C. (2004). The development of a reproducible Agrobacterium tumefaciens transformation system for garlic (Allium sativum L.) and the production of transgenic garlic resistant to beet armyworm (Spodoptera exigua Hübner). Mol. Breed. 14, 293 307. doi: 10.1023/B:MOLB.0000047775.83715.b5

Zheng, S.-J., Khrustaleva, L., Henken, B., Sofiari, E., Jacobsen, E., Kik, C., et al. (2001). Agrobacterium tumefaciens-mediated transformation of Allium cepa L.: the production of transgenic onions and shallots. Mol. Breed. 7, 101-115. doi: 10.1023/A:1011348229189

Zsögön, A., Cermak, T., Voytas, D., and Peres, L. E. P. (2017). Genome editing as a tool to achieve the crop ideotype and de novo domestication of wild relatives: case study in tomato. Plant Sci. 256, 120-130. doi: 10.1016/j.plantsci.2016. 12.012

Conflict of Interest Statement: The authors declare that the research was conducted in the absence of any commercial or financial relationships that could be construed as a potential conflict of interest.

Copyright (c) 2017 Cardi, D'Agostino and Tripodi. This is an open-access article distributed under the terms of the Creative Commons Attribution License (CC BY). The use, distribution or reproduction in other forums is permitted, provided the original author(s) or licensor are credited and that the original publication in this journal is cited, in accordance with accepted academic practice. No use, distribution or reproduction is permitted which does not comply with these terms. 